\title{
AN OVERVIEW OF ANTI-TUBERCULOSIS TREATMENT (ATT) IN CAT I NEWLY DIAGNOSED CASES OF TUBERCULOSIS IN RNTCP
}

\author{
Ratan Kumar', Rajesh Kumar Ahirwar ${ }^{2}$, Lokendra Dave ${ }^{3}$, Nishant Srivastava ${ }^{4}$, Nawal Kapoor $^{5}$, Pritesh Goutam ${ }^{6}$, Atul Kharate ${ }^{7}$, \\ Shyam Krishna Vaish $^{8}$ \\ ${ }^{1}$ Associate Professor, Department of Pulmonary Medicine, LN Medical College, Bhopal, Madhya Pradesh. \\ ${ }^{2}$ Associate Professor, Department of Community Medicine, LN Medical College, Bhopal, Madhya Pradesh. \\ ${ }^{3}$ Professor and HOD, Department of TB and Chest, Gandhi Medical College, Bhopal, Madhya Pradesh. \\ ${ }^{4}$ Associate Professor, Department of TB and Chest, Gandhi Medical College, Bhopal, Madhya Pradesh. \\ ${ }^{5}$ Assistant Professor, Department of Paediatrics, LN Medical College, Bhopal, Madhya Pradesh. \\ ${ }^{6}$ Assistant Professor, Department of Psychiatry, LN Medical College, Bhopal, Madhya Pradesh. \\ ${ }^{7}$ State Tuberculosis Officer, Madhya Pradesh. \\ ${ }^{8}$ Medical Officer/Junior Resident, Uttar Pradesh.
}

\section{ABSTRACT}

\section{BACKGROUND}

Tuberculosis (TB) remains a global public health problem and a major cause of death from a single infectious agent among adults in India and other developing countries. The aim of this study is to characterise effectiveness and outcome of antituberculosis treatment among newly diagnosed patients in RNTCP.

\section{MATERIALS AND METHODS}

This is a retrospective descriptive study of a newly diagnosed TB patients of all age groups attending OPD of various departments of LN Medical College and JK Hospital, Bhopal, M. P. (India) between a period of January 2012 and September 2015.

\section{RESULTS}

A total of 360 patients were found eligible for this study, who were diagnosed and received ATT under DOTS in RNTCP. In different age groups percentage of patients observed were $14.72 \%, 65.28 \%$ and $20.00 \%$ in 0 - 14 years, 15 - 45 years and above 45 years respectively.

\section{CONCLUSION}

Maximum patients $65.28 \%$ (235) were registered in the age group of 15 - 45 years. Overall, treatment outcome were observed as follows- $86.39 \%$ treatment successful, $6.11 \%$ defaulted, $2.78 \%$ failed and $4.17 \%$ died. Higher percentage of treatment successful $(98.11 \%)$ was observed in the age group of 0 - 14 years, whereas higher percentage of both defaulter (12.50\%) and mortality $(15.28 \%)$ with lower treatment successful rate $(68.06 \%)$ were observed in the age group of above 45 years. Higher percentage of defaulter, failure and mortality were observed in males and PTB patients in comparison to females and EPTB. Overall, significant weight gain (92.60\%) with treatment being successful (86.39\%) were observed in this study.

\section{KEYWORDS}

ATT, Newly Diagnosed TB, DOTS, RNTCP.

HOW TO CITE THIS ARTICLE: Kumar R, Ahirwar RK, Dave L, et al. An overview of anti-tuberculosis treatment (ATT) in CAT I newly diagnosed cases of tuberculosis in RNTCP. J. Evolution Med. Dent. Sci. 2017;6(54):4052-4056, DOI: $10.14260 /$ Jemds/2017/876

\section{BACKGROUND}

Tuberculosis (TB) remains a global public health problem and a major cause of death from a single infectious agent among adults in India and other developing countries.[1,2,3,4] The problem is further compounded by the emergence of HIV, DM and DR (Drug Resistance) TB. According to WHO 6.1 million TB cases were reported in 2013, out of which 5.7 million cases were newly diagnosed and another 0.4 million were already on treatment.[5]

The burden of TB in India is the highest accounting for approximately one-fifth (21\%) of the global incidence.[6]

Financial or Other, Competing Interest: None.

Submission 19-05-2017, Peer Review 23-06-2017,

Acceptance 29-06-2017, Published 06-07-2017.

Corresponding Author:

Dr. Ratan Kumar,

Department of Pulmonary Medicine,

LN Medical College, Bhopal,

Madhya Pradesh, India.

E-mail: ratan_vaish@yahoo.co.in

DOI: $10.14260 /$ jemds $/ 2017 / 876$ which 0.8 million are infectious.[7] As per Revised National Tuberculosis Control Programme (RNTCP) 2011 in Madhya Pradesh, there were 90,764 cases registered for TB.[8]

In India, National Tuberculosis Control Programme (NTP) was launched in 1962. NTP was integrated and implemented through the general public health services.[9] NTP could not achieve the objective because of low priority, managerial weakness, over dependence on x-ray chest for diagnosis and inadequate funding. In order to overcome the shortcomings in the NTP, WHO and Government of India revised the programme jointly in 1992. WHO declared TB, a global health emergency in April 1993.[10] The Revised National Tuberculosis Programme (RNTCP) has been implemented in 1993, guided by WHO and supported by world bank.[11]

A five-point strategy known as Directly Observed Treatment Short course (DOTS) was launched in India in a phased manner under RNTCP in 1997 with objective of cure rate not less than $85 \%$ of infectious TB cases and at least $70 \%$ detection of new cases through quality sputum microscopy.[12,13] 
With this background, we conducted this retrospective study at LN Medical College and JK Hospital, Bhopal, M. P. (India).

\section{MATERIALS AND METHODS \\ Aim}

The aim of this study is to characterise effectiveness and outcome of antituberculosis treatment among newly diagnosed patients in RNTCP.

\section{Study Design}

This is retrospective descriptive study of newly diagnosed TB patients of all age groups.

\section{Study Areas}

The study was conducted in the LN Medical College and JK Hospital, Bhopal (MP), a tertiary care centre, so patients from urban, nearby villages and adjoining districts who were referred for diagnosis and treatment of tuberculosis.

\section{Study Period}

Data for this study has been obtained between a period of January 2012 and September 2015.

\section{Study Population}

The population includes all patients attending various OPD of this institute who suspected of TB infection during the study period. This study includes a total of 360 patients diagnosed microbiologically, pathologically and radiologically as TB in LN Medical College and JK Hospital, Bhopal (MP).

\section{Source of Information}

For this study data has been obtained from DOTS treatment cards, RNTCP referral register, patient record sheet of hospital and laboratory register.

\section{Inclusion Criteria}

All new tuberculosis patients of any age group registered as per RNTCP guidelines.

\section{Exclusion Criteria}

Patients having comorbid diseases like DR, TB and HIV. The patients were started on standard regimens of antituberculosis drugs as provided by Government of India under DOTS for category I patients. During intensive phase, every dose of anti-tuberculosis drugs were taken in front of health worker or DOTS provider followed by continuation phase during which first dose of weekly ATT pack were given under direct observation of health worker or DOTS provider and remaining two doses of weekly pack has been taken by patient themselves at their home.

Data were scrutinised and cross checked twice in order to ensure accuracy and corrected for discrepancy or any missing information.

\section{Definitions \\ Cured}

Initially, sputum smear positive patients who have completed treatment and have negative sputum smear on at least two occasions, out of which one at completion of treatment.

\section{Treatment Completed}

Sputum negative patients who had received full course of ATT has not become smear positive during or at the end of the treatment.

\section{Defaulted}

A patient who had not taken ATT for one month or more consecutively after one month of starting the treatment.

\section{Failure}

Smear positive cases who remain smear positive at 5 months or more after starting the treatment. Also includes patients who was initially smear negative, but become positive during treatment.

\section{Died}

Patient who died during treatment regardless of cause of death.

\section{Transfer Out}

A patient who has been transferred to another TB unit/district and for whom the treatment results (outcome) is not known.

\section{Treatment Successful}

The sum of 'cured' and 'treatment completed' patients.

\section{RESULTS}

A total of 360 patients were found eligible for this study, who were diagnosed as new cases of tuberculosis and started CAT I ATT under DOTS in RNTCP. Out of total patients, 55.00\% (198) were male and $45.00 \%$ (162) were female. Patients registered of pulmonary tuberculosis and EPTB were $65.56 \%$ (236) and 34.44\% (124). Maximum patients 65.28\% (235) were registered in the age group of $15-45$ years and minimum $14.72 \%$ (53) were found in the age group of $0-14$ years. Maximum 58.08\% (115) and 74.07\% (120) of total male and female patients were also registered in the same age group of 15 - 45 years.

Overall treatment outcome was observed as follows$86.39 \%$ (311) treatment successful, $27.78 \%$ (100) cured, $58.61 \%$ (211) treatment completed, $6.11 \%$ (22) defaulted, $2.78 \%$ (10) failed, $0.00 \%$ (0) relapsed, $4.17 \%$ (15) died and $0.56 \%$ (2) transferred out. Successful treatment in patients were observed as follows- 80.81\% (160), 93.21\% (151), $82.20 \%$ (194) and $94.35 \%$ (117) respectively in males, females, pulmonary TB and EPTB patients. Higher percentage of defaulter, failure and mortality were $8.08 \%(16), 3.03 \%(6)$ and $7.07 \%$ (14) observed in males as compared to female patients. Higher percentage of defaulter, failure and mortality were $8.05 \%$ (19), 3.81\% (9) and 5.08\% (12) observed in pulmonary TB patients as compared to EPTB patients. Out of total 236 treated patients of pulmonary tuberculosis, treatment outcomes were observed as follows- $82.20 \%$ (194) treatment successful, $42.37 \%$ (100) cured, 39.83\% (94) treatment completed, $8.05 \%$ (19) defaulted, 3.81\% (9) failed, $0.00 \%$ (0) relapsed, $5.08 \%$ (12) died and $0.85 \%$ (2) transferred out.

Out of total 130 sputum smear positive PTB patients, cure rate, defaulted, failed and died were observed as $76.92 \%$ (100), $10.00 \%$ (13), 6.92\% (9) and 5.38\% (7) respectively. 
In sputum smear positive patients, higher percentage of treatment successful $79.60 \%$ (78) was observed in the age group below 45 years, while higher rate of default (18.75\%) and mortality $(12.50 \%)$ were observed in the age group of above 45 years.

In this study overall weight gain, weight constant and weight loss observed were $92.60 \%$ (288), 3.86\% (12) and $3.54 \%$ (11) patients.
Higher percentage of treatment successful was $98.11 \%$ (52) observed in the age group of 0 - 14 years, while higher percentage of both defaulter (12.50\%) and mortality $(15.28 \%)$ were observed in the age group of above 45 years as compared to other age groups.

\begin{tabular}{|c|c|c|c|c|}
\hline Group & $\begin{array}{c}\mathbf{0 - 1 4} \text { yrs. } \\
\mathbf{1 4 . 7 2 \%}(\mathbf{5 3})\end{array}$ & $\begin{array}{c}\mathbf{1 5 - 4 5} \text { yrs. } \\
\mathbf{6 5 . 2 8 \%}(\mathbf{2 3 5})\end{array}$ & $\begin{array}{c}\text { Above 45 yrs. } \\
\mathbf{2 0 . 0 0 \%}(\mathbf{7 2})\end{array}$ & Total (360) \\
\hline Male & $16.67 \%(33)$ & $58.08 \%(115)$ & $25.25 \%(50)$ & $55.00 \%(198)$ \\
\hline Female & $12.35 \%(20)$ & $74.07 \%(120)$ & $13.58 \%(22)$ & $45.00 \%(162)$ \\
\hline EPTB & $16.13 \%(20)$ & $68.55 \%(85)$ & $15.32 \%(19)$ & $34.44 \%(124)$ \\
\hline Pulmonary TB & $13.98 \%(33)$ & $63.56 \%(150)$ & $22.46 \%(53)$ & $65.56 \%(236)$ \\
\hline Sputum positive TB & $0.77 \%(1)$ & $73.08 \%(95)$ & $26.15 \%(34)$ & $36.11 \%(130)$ \\
\hline Sputum negative TB & $30.19 \%(32)$ & $51.89 \%(55)$ & $17.92 \%(19)$ & $29.44 \%(106)$ \\
\hline Weight gain & $17.71 \%(51)$ & $66.32 \%(191)$ & $15.97 \%(46)$ & $92.60 \%(288 / 311)$ \\
\hline Weight constant & $8.33 \%(1)$ & $83.34 \%(10)$ & $8.33 \%(1)$ & $3.86 \%(12 / 311)$ \\
\hline Table 1. Age Wise distribution of Patients in different Group of Sex, Site Involvement, Sputum Status and Weight Variation
\end{tabular}

\begin{tabular}{|c|c|c|c|c|c|c|c|c|c|}
\hline & $\begin{array}{c}\text { Treatment } \\
\text { Successful } \\
86.39 \% \\
(311) \\
\end{array}$ & $\begin{array}{c}\text { Cured } \\
27.78 \% \\
(100)\end{array}$ & $\begin{array}{c}\text { Treatment } \\
\text { Completed } \\
58.61 \% \\
(211) \\
\end{array}$ & $\begin{array}{c}\text { Default } \\
6.11 \% \\
(22)\end{array}$ & $\begin{array}{c}\text { Failure } \\
2.78 \% \\
(10)\end{array}$ & $\begin{array}{c}\text { Relapsed } \\
0.0 \%(0)\end{array}$ & $\begin{array}{c}\text { Expired } \\
4.17 \% \\
(15)\end{array}$ & $\begin{array}{c}\text { Transfer } \\
\text { Out } \\
0.56 \% \\
(2) \\
\end{array}$ & $\begin{array}{l}\text { Total } \\
(360)\end{array}$ \\
\hline $0-14$ yrs. & $\begin{array}{c}98.11 \% \\
(52) \\
\end{array}$ & $\begin{array}{c}1.89 \% \\
(1)\end{array}$ & $\begin{array}{c}96.23 \% \\
(51)\end{array}$ & $\begin{array}{c}1.89 \% \\
(1)\end{array}$ & $\begin{array}{c}0.0 \% \\
(0)\end{array}$ & $\begin{array}{c}0.0 \% \\
(0)\end{array}$ & $\begin{array}{c}0.0 \% \\
(0)\end{array}$ & $\begin{array}{c}0.0 \% \\
(0)\end{array}$ & $\begin{array}{c}14.72 \% \\
(53)\end{array}$ \\
\hline $15-45$ yrs. & $\begin{array}{c}89.36 \% \\
(210)\end{array}$ & $\begin{array}{c}32.77 \% \\
(77)\end{array}$ & $\begin{array}{c}56.60 \% \\
(133)\end{array}$ & $\begin{array}{c}5.11 \% \\
(12)\end{array}$ & $\begin{array}{c}3.83 \% \\
(9)\end{array}$ & $\begin{array}{c}0.0 \% \\
(0)\end{array}$ & $\begin{array}{c}1.70 \% \\
(4)\end{array}$ & $\begin{array}{c}0.0 \% \\
(0)\end{array}$ & $\begin{array}{c}65.28 \% \\
(235)\end{array}$ \\
\hline Above 45 yrs. & $\begin{array}{c}68.06 \% \\
(49)\end{array}$ & $\begin{array}{c}30.56 \% \\
(22)\end{array}$ & $\begin{array}{c}37.50 \% \\
(27)\end{array}$ & $\begin{array}{c}12.50 \% \\
\text { (9) }\end{array}$ & $\begin{array}{c}1.39 \% \\
(1)\end{array}$ & $\begin{array}{c}0.0 \% \\
(0)\end{array}$ & $\begin{array}{c}15.28 \% \\
(11)\end{array}$ & $\begin{array}{c}2.78 \% \\
(2)\end{array}$ & $\begin{array}{c}20.00 \% \\
(72)\end{array}$ \\
\hline Male & $\begin{array}{c}80.81 \% \\
(160)\end{array}$ & $\begin{array}{c}27.27 \% \\
(54)\end{array}$ & $\begin{array}{c}53.54 \% \\
(106)\end{array}$ & $\begin{array}{c}8.08 \% \\
(16)\end{array}$ & $\begin{array}{c}3.03 \% \\
(6)\end{array}$ & $\begin{array}{c}0.0 \% \\
(0)\end{array}$ & $\begin{array}{c}7.07 \% \\
(14)\end{array}$ & $\begin{array}{c}1.01 \% \\
(2)\end{array}$ & $\begin{array}{c}55.00 \% \\
(198)\end{array}$ \\
\hline Female & $\begin{array}{c}93.21 \% \\
(151)\end{array}$ & $\begin{array}{c}28.40 \% \\
(46)\end{array}$ & $\begin{array}{c}64.81 \% \\
(105)\end{array}$ & $\begin{array}{c}3.70 \% \\
(6)\end{array}$ & $\begin{array}{c}2.47 \% \\
(4)\end{array}$ & $\begin{array}{c}0.0 \% \\
(0)\end{array}$ & $\begin{array}{c}0.61 \% \\
(1)\end{array}$ & $\begin{array}{c}0.0 \% \\
(0)\end{array}$ & $\begin{array}{c}45.00 \% \\
(162)\end{array}$ \\
\hline ЕРТВ & $\begin{array}{c}94.35 \% \\
(117)\end{array}$ & $\begin{array}{c}0.0 \% \\
(0)\end{array}$ & $\begin{array}{c}94.35 \% \\
\text { (117) }\end{array}$ & $\begin{array}{c}2.42 \% \\
(3)\end{array}$ & $\begin{array}{c}0.81 \% \\
(1)\end{array}$ & $\begin{array}{c}0.0 \% \\
(0)\end{array}$ & $\begin{array}{c}2.42 \% \\
(3)\end{array}$ & $\begin{array}{c}0.0 \% \\
(0)\end{array}$ & $\begin{array}{c}34.44 \% \\
(124)\end{array}$ \\
\hline РTB & $\begin{array}{c}82.20 \% \\
(194)\end{array}$ & $\begin{array}{c}42.37 \% \\
(100)\end{array}$ & $\begin{array}{c}39.83 \% \\
(94)\end{array}$ & $\begin{array}{c}8.05 \% \\
(19)\end{array}$ & $\begin{array}{l}3.81 \% \\
(9)\end{array}$ & $\begin{array}{c}0.0 \% \\
(0)\end{array}$ & $\begin{array}{c}5.08 \% \\
(12)\end{array}$ & $\begin{array}{l}0.85 \% \\
\text { (2) }\end{array}$ & $\begin{array}{c}65.56 \% \\
(236)\end{array}$ \\
\hline $\begin{array}{c}\text { Sputum Neg. } \\
\text { PTB }\end{array}$ & $\begin{array}{c}88.68 \% \\
(94)\end{array}$ & $\begin{array}{c}0.0 \% \\
(0)\end{array}$ & $\begin{array}{c}88.68 \% \\
(94)\end{array}$ & $\begin{array}{c}5.66 \% \\
(6)\end{array}$ & $\begin{array}{c}0.0 \% \\
(0)\end{array}$ & $\begin{array}{c}0.0 \% \\
(0)\end{array}$ & $\begin{array}{c}4.72 \% \\
(5)\end{array}$ & $\begin{array}{c}0.94 \% \\
(1)\end{array}$ & $\begin{array}{c}29.44 \% \\
(106) \\
\end{array}$ \\
\hline $\begin{array}{c}\text { Sputum Pos. } \\
\text { PTB }\end{array}$ & $\begin{array}{c}76.92 \% \\
(100)\end{array}$ & $\begin{array}{c}76.92 \% \\
(100)\end{array}$ & $\begin{array}{c}0.0 \% \\
(0)\end{array}$ & $\begin{array}{c}10.00 \% \\
(13)\end{array}$ & $\begin{array}{c}6.92 \% \\
(9)\end{array}$ & $\begin{array}{c}0.0 \% \\
(0)\end{array}$ & $\begin{array}{c}5.38 \% \\
(7)\end{array}$ & $\begin{array}{l}0.77 \% \\
(1)\end{array}$ & $\begin{array}{c}36.11 \% \\
(130)\end{array}$ \\
\hline $\begin{array}{l}\text { Sputum } \\
\text { Positive } \\
\text { < } 45 \text { yrs. }\end{array}$ & $\begin{array}{c}79.60 \% \\
(78)\end{array}$ & $\begin{array}{c}79.60 \% \\
(78)\end{array}$ & $\begin{array}{c}0.0 \% \\
(0)\end{array}$ & $\begin{array}{l}7.14 \% \\
(7)\end{array}$ & $\begin{array}{l}9.18 \% \\
(9)\end{array}$ & $\begin{array}{c}0.0 \% \\
(0)\end{array}$ & $\begin{array}{c}3.06 \% \\
(3)\end{array}$ & $\begin{array}{l}1.02 \% \\
(1)\end{array}$ & $\begin{array}{c}27.22 \% \\
\quad(98)\end{array}$ \\
\hline $\begin{array}{l}\text { Sputum } \\
\text { Positive } \\
>45 \text { yrs. }\end{array}$ & $\begin{array}{l}68.75 \% \\
(22)\end{array}$ & $\begin{array}{c}68.75 \% \\
(22)\end{array}$ & $\begin{array}{c}0.0 \% \\
(0)\end{array}$ & $\begin{array}{c}18.75 \% \\
(6)\end{array}$ & $\begin{array}{c}0.0 \% \\
(0)\end{array}$ & $\begin{array}{c}0.0 \% \\
(0)\end{array}$ & $\begin{array}{c}12.50 \% \\
(4)\end{array}$ & $\begin{array}{c}0.0 \% \\
(0)\end{array}$ & $\begin{array}{c}8.89 \% \\
(32)\end{array}$ \\
\hline
\end{tabular}

\section{DISCUSSION}

This present study was done to categorise the efficacy and treatment outcome of ATT drugs in tuberculosis patients put on DOTS in RNTCP. In this study, higher proportion of males $55.00 \%$ were affected by TB as compared to females. Higher proportion of males were also observed in study at Nagpur (68.99\%).[14] In this study $45 \%$ female patients were registered, while $31.01 \%$ female patients were registered in study at Nagpur.[14]

In this study, maximum patients $65.28 \%$ were registered in the age group of $15-45$ years, which reflects that tuberculosis disease is more commonly affecting reproductive and working population in both males and females which can affect the scenario of economy of any country. 
In this study successful treatment rate observed were 86.39\% which coincides with $96.13 \%, 78.10 \%$ and $77.14 \%$ found in different studies at Nagpur, Zenebe $\mathrm{Y}$ et al and Aurangabad respectively.[14,15,16]

The cure rate was calculated as $27.78 \%$ in this study. This data coincide with $35.24 \%, 45.74 \%, 47.66 \%$ and $13.80 \%$ found in different studies at Aurangabad, Nagpur, Delhi and Jemal $M$ et al.[14,16,17,18]

Overall treatment completed patients observed in this study were $58.61 \%$, while $50.39 \%, 41.90 \%$ and $51.50 \%$ were observed in different studies done at Nagpur, Aurangabad and Jemal $\mathrm{M}$ et al.[14,16,18]

Overall default rate in this study is $6.11 \%$, which coincides with $5.98 \%, 2.33 \%, 19.05 \%$ and $3.80 \%$ observed in different studies at Delhi, Nagpur, Aurangabad and Jemal M et al.[14,16,17,18] The average rate of default in India were $4 \%$ among Category I.[7] As age advanced, percentage of defaulters increased in this study from $1.89 \%$ in 0 - 14 years age group to $12.50 \%$ in the age group above 45 years. The percentage of defaulters was high among males, $8.08 \%$. Possible causes of default may be feeling of wellbeing in early phase of treatment, side effect of drugs, facing difficulty to attend DOTS centre, financial loss on day of medication due to absence from work, social stigma to attend DOTS centre, rude behaviour of some DOTS provider, less faith towards government health organisations and migration of labourers. Continuing education and motivation can reduce defaults at all stage of treatment. To reduce default rate and increase case detection, it is suggested that government should also provide ATT under DOTS by mobile van with in-built facilities of sputum smear examination, portable chest x-ray machine, trained staff and medicines to treat side effect of ATT.

Dense population, little health awareness, increasing trend of nuclear family, unhealthy lifestyle, increasing stress in job, lesser pre-employment heath checkup of maids/drivers and affecting young adults are major risk factors for delayed diagnosis, delay in starting of treatment and increasing burden of Category I TB and later Category II/ DRTB which can affect individual family condition and economy of country as well.

Total sputum smear positive patients observed in this study was $36.11 \%$ while $45.42 \%, 47.62 \%, 66.67 \%$, $26.80 \%$ and $9.8 \%$ were observed in different studies done at Delhi, Aurangabad, Nagpur, Jemal $M$ et al and Zenebe $Y$ et al.[14,15,16,17,18]

Total sputum smear negative pulmonary TB patients observed in this study was $29.44 \%$, while $23.25 \%$ and $31.80 \%$ were observed in different studies done at Nagpur and Zenebe $Y$ et al.[14,15]

All family members, close contact of specially sputum positive patients should be strictly evaluated for early detection of tuberculosis and early starting of ATT.

In present study overall failure rate was observed in $2.78 \%$ while $1.12 \%, 0.78 \%$ and $0.7 \%$ were observed in study of Delhi, Nagpur and Jemal $M$ et al respectively.[14,17,18] However, it was comparable with average rate of India, i,e. $1.5 \%$ Category I.[6]

As per RNTCP data the prevalence of EPTB in non-HIV patients was $15-20 \%$, but in this study it was $34.44 \%$ which is more than the RNTCP statistics. This increase in prevalence of EPTB is due to easy availability of advanced diagnostic facilities at low cost in medical college setup[19] and ours is a tertiary care referral centre.

Overall death rate in this study observed was $4.17 \%$ while $2.86 \%, 2.80 \%, 0.93 \%$ and $0.78 \%$ found in different studies at Aurangabad, Jemal M et al, Delhi and Nagpur.[14,16,17,18]

The treatment successful rate $(68.06 \%)$ were low, but rate of default $(12.50 \%)$ and mortality $(15.28 \%)$ were high among elderly patients age above 45 years. Tuberculosis in elderly age group is most often associated with reactivation of endogenous infection, poor nutritional status, comorbidities, atypical clinical features, delayed diagnosis and neglected by some family members, so patients seek medical advice in more advanced stage which can lead to higher mortality.

Overall weight gain, weight constant and weight loss were observed in $92.60 \%, 3.86 \%$ and $3.54 \%$ patients in this study, which coincides with $91.10 \%, 5.6 \%$ and $3.30 \%$ in Chennai study.

This study shows that anti-tuberculosis treatment under DOTS in RNTCP is running successfully in the study region with good success rate and low default rates.

This study had several limitations; the main limitation is that being a retrospective and tertiary care level hospitalbased study, finding cannot be generalised/applied to the whole community, but it gives important information regarding tuberculosis management under DOTS in Bhopal, M.P. (India).

\section{CONCLUSION}

This study showed that tuberculosis disease is now more affecting young adult population, which is a very worrisome fact. In different age groups percentage of patients observed were $14.72 \%, 65.28 \%$ and $20.00 \%$ in $0-14$ years, $15-45$ years and above 45 years respectively.

Overall treatment outcome was observed as follows$86.39 \%$ treatment successful, $6.11 \%$ defaulted, $2.78 \%$ failed and $4.17 \%$ died.

Higher percentage of successful treatment was $98.11 \%$ observed in the age group of $0-14$ years as compared to other age group. Higher percentage of both defaulter $(12.50 \%)$ and mortality $(15.28 \%)$ with lower treatment successful rate $(68.06 \%)$ were observed in the patient's age group of above 45 years as compared to other age groups.

Overall, significant weight gain $(92.60 \%)$ with successful treatment $(86.39 \%)$ were observed in this study.

\section{List of Abbreviations- \\ EPTB - Extra-Pulmonary Tuberculosis. \\ PTB - Pulmonary Tuberculosis. \\ ATT - Anti-Tuberculosis Treatment. \\ TB - Tuberculosis. \\ RNTCP - Revised National Tuberculosis Control Programme \\ DOTS - Directly Observed Treatment Short Course Chemotherapy. \\ HIV - Human Immunodeficiency Virus. \\ DR - Drug Resistance. \\ DM - Diabetes Mellitus.}

\section{ACKNOWLEDGEMENT}

The authors express deep gratitude to all RNTCP officials including MP State STF Chairman - RNTCP, State Tuberculosis Officer, Dr. A. K. Shrivastava, DTO - Bhopal and 
MO-DOTS centre ( J.K. Hospital) for the use of DOTS Centre data. Additionally, we would like to thank all the participants, DOTS provider, and microscopy technician at DOTS centre. We also recognize the peer reviewers whose suggestions greatly improved this manuscript as well as Astha Agrahari, Divyansh Dinanath Vaish, Vikrant and Kashish.

\section{REFERENCES}

[1] Kumar R, Ahirwar RK, Dave L, et al. Study of weight variation during anti-tuberculosis treatment in tuberculosis patients put on dots in RNTCP in central India. J Evolution Med Dent Sci 2017;6(6):478-81.

[2] Tuberculosis fact sheet $\mathrm{N}^{\circ} 104$. World Health Organization 2011. www.who.int/mediacentre/facts heets/fs104/en/.

[3] Stop TB. Geneva: World Health Organization. Partnership and World Health Organization. An international roadmap for tuberculosis research 2011.

[4] New Delhi: Directorate general of health services, ministry of health and family welfare nirman bhavan. Government of India. Managing the revised national tuberculosis control programme in your area. A training course-modules (1-4)-central TB division 2010:P1.

[5] Global tuberculosis control 2014, WHO, Geneva 2014. www.who.int/tb/publications/global_report/en/.

[6] District wise performance of RNTCP. TB India 2011:114-5. http://www.tbcindia.org ISBN 81902652-5-3.

[7] Central TB division, directorate general of health services, ministry of health and family welfare, nirman bhavan, New Dehli. TB India 2006, RNTCP status report 2006:12,56-58.

[8] TB statistics for India-TB Facts.org 2012. Available at http://wwwtbfacts.org/tb-statics-india.html.

[9] Nagpual DR. India's national tuberculosis program an overview. Intl J Tub 1989;36:205.
[10] Narain JP, Lo YR. Epidemiology of HIV-TB in Asia. Indian J Med Res 2004;120(4):277-89.

[11] Khatri GR, Frieden TR. The status and prospectus of tuberculosis control in India. Int J Tuberc Lung Dis 2000;4(3):193-200.

[12] TB India 2007. RNTCP status report. Central tuberculosis division, New Delhi 2007:P106. http://www.tbcindia.org.

[13] Holmes CB, Hausler H, Nunn P. A review of sex differences in the epidemiology of tuberculosis. Int J Tuberc Lung Dis 1998;2(2):96-104.

[14] Choudhary S, Tayade B, Keshwani P. Efficacy and treatment outcome of DOTS in RNTCP. Panacea Journal Of Medical Sciences 2012;2(1):32-6.

[15] Zenebe Y, Adem Y, Mekonnen D, et al. Profile of tuberculosis and its response to anti-TB drugs among tuberculosis patients treated under the TB control programme at felege-hiwot referral hospital, Ethiopia. BMC Public Health 2016;16:688.

[16] Karanjekar VD, Lokare PO, Gaikwad AV, et al. Treatment outcome and follow up of tuberculosis patients put on directly observed treatment shortcourse under rural health training center, Paithan, Aurangabad in India. Ann Med Health Sci Res 2014;4(2):222-6.

[17] Chadha SL, Bhagi RP. Treatment outcome in tuberculosis patients placed under directly observed treatment short course (DOTS)-a cohort study. Indian J Tuberc 2000;47:155-8.

[18] Jemal M, Tarekegne D, Atanaw T, et al. Treatment outcomes of tuberculosis patients in metema hospital, Northwest Ethiopia: a four years retrospective study. Mycobact Dis 2015;5:190.

[19] Shrivastava AK, Brahmachari S, Pathak P, et al. Clinicoepidemiological profile of extra-pulmonary tuberculosis in Central India. Int J Med Res Rev 2015;3(2):223-30. 